\title{
Early childhood caries and risk factors in young children of medium-low socioeconomic status, Ecuador
}

\author{
Janeth Parra-Coronel' ${ }^{1}$, Diana Astudillo-Neira², Johana Ortiz-Ulloa ${ }^{2}$
}

\begin{abstract}
Introduction. Early childhood caries (ECC) is one of the most common infectious diseases for infants and preschool children.

Objective: To evaluate early childhood caries and risk factors associated with dietary practices and nutritional status in children of 10-48 months old.

Materials and Methods: A cross-sectional study was performed on 142 children of medium-low socio-economic status from a governmental child-care center in Cuenca, Ecuador. Dental health, nutritional status and dietary patterns were assessed through clinical examination, anthropometric measurements and 24-hours dietary recalls, respectively.

Results: Early childhood caries prevalence was high (95.8\%) mostly of advanced stage (83.1\%). No associations with nutritional status. Daily consumption of cariogenic foods was significantly higher during weekdays (11.1 \pm 1.4) $(p<0.001)$. The diet was categorized as low cariogenic risk $(<34)$. Child's age $(\mathrm{OR}=1.1 ; 95 \% \mathrm{Cl}: 1.041,1.160$, $\mathrm{p}=0.001)$ and the plaque index $(\mathrm{OR}=4.9 ; 95 \% \mathrm{Cl}: 1.331,17.82 ; \mathrm{p}=0.017)$ were positive determinants for advanced caries.

Conclusions: The deteriorated dental health of this population was evidenced, being worse at older ages without any association with dietary patterns.

Key words: dental caries, nutritional status, child, diet, cariogenic agents.

${ }^{1}$ Faculty of Dentistry, Cuenca University, Cuenca, Ecuador

2 Department of Biosciences, Food Nutrition and Health Research Unit. Faculty of Chemical Sciences, Cuenca University. Cuenca, Ecuador. Correspondence author: Janeth Parra-Coronel. Faculty of Dentistry, Cuenca University, Av. El Paraíso s/n. P.O.Box 01.01.168. Cuenca, Ecuador. Email: judith.parra@ucuenca.edu.ec. Telephone: +5937405100 Ext. 3200
\end{abstract}

Citar este artículo así:

Parra-Coronel J, Astudillo-Neira D, Ortiz-Ulloa J. Early childhood caries and risk factors in young children of medium-low socioeconomic status, Ecuador. Revista Investig Salud Univ Boyacá. 2020;7(1): 52-70. doi: https://doi.org/10.24267/23897325.451 


\section{Caries de la temprana infancia y factores de riesgo en niños de nivel socioeconómico medio-bajo, Ecuador}

\section{RESUMEN}

Introducción: La caries de la temprana infancia (CTI) es una de las enfermedades infecciosas más comunes en infantes y niños preescolares.

Objetivo: Evaluar la caries de la temprana infancia y los factores de riesgo asociados con prácticas dietarías y el estado nutricional en niños de 10-48 meses de edad.

Materiales y Métodos: Se realizó un estudio transversal en 142 niños de nivel socioeconómico medio-bajo de un centro infantil gubernamental en Cuenca, Ecuador. La salud dental, estado nutricional y patrones dietarios se evaluaron mediante exámenes clínicos, mediciones antropométricas y recordatorios de 24 horas, respectivamente.

Resultados: La prevalencia de caries de la temprana infancia fue alta (95.8\%) mayoritariamente en etapa avanzada (83.1\%). No se observaron asociaciones con el estado nutricional. El consumo diario de alimentos cariogénicos fue significativamente mayor entre semana $(11,1 \pm 1,4)(p<0,001)$. La dieta fue categorizada como de bajo riesgo cariogénico $(<34)$. La edad del niño $(O R=1.1$; IC 95\%: 1.041, 1.160, $p=0.001)$ y el índice de placa $(\mathrm{OR}=4.9$; IC 95\%: 1.331, 17.82; $\mathrm{p}=0.017)$ fueron determinantes positivos de caries avanzada.

Conclusión: El deterioro de la salud dental de esta población se evidenció, empeorando a edades mayores sin asociación con los patrones dietarios.

Palabras clave: caries dental, estado nutricional, niño, dieta, agentes cariogénicos. 


\section{Cárie na primeira infância e fatores de risco em crianças de nível socioeconômico médio-baixo, Equador}

\section{RESUMO}

Introdução. A cárie da primeira infância (CPI) é uma das enfermidades infecciosas mais comuns em crianças pre-escolares.

Objetivo: Avaliar a cárie da primeira infância e fatores de risco associados com práticas dietárias e estado nutricional de crianças de 10-48 meses.

Materiais e métodos. Realizou-se um estudo transversal em 142 crianças de nível socioeconômico médio-baixo do centro infantil governamental em Cuenca, Equador. A saúde dental, estado nutricional e patroes dietários se avaliaram mediante exames clínicos, medições antropométricas e lembretes de 24 horas respectivamente.

Resultados: A prevalência de cárie da primeira infância foi alta (95.8\%) principalmente em estágio avançado (83.1\%). Não se observaram relações com o estado nutricional. O consumo diário de alimentos cariogênicos foi significativamente maior entre semana $(11,1 \pm 1,4)(p<0,001)$. A dieta foi categorizada como de baixo risco cariogênico (<34). A idade das crianças (OR=1.1; IC 95\%: 1.041, $1.160, p=0.001)$ e o índice de placa ( $O R=4.9$; IC 95\%: 1.331, 17.82; $p=0.017)$ foi determinante em cárie avançada positiva.

Conclusão: O deterioro da saúde dental dessa população se evidenciou, piorando as idades mais velhas sem relação com os patroes dietários.

Palavras-Chave: cárie dental, estado nutricional, criança, dieta, agente cariogênicos 


\section{INTRODUCTION}

Early childhood caries (ECC) is one of the most common infectious diseases affecting dentition of $60-90 \%$ of infants and preschool children (1). In addition, ECC is considered a good marker of social inequalities, being a common health problem among vulnerable communities such as indigenous and ethnic minority groups (2). In Latin America, ECC prevalence fluctuates between $44-93 \%$ (3-6). ECC is mainly a result of the presence of bacterial plaque in combination with other factors such as deficient oral hygiene practices, lack of knowledge of the parents and child caring personnel and deprived socioeconomic conditions (7-10). Moreover, cariogenic diet is one of the major etiological factors of ECC.

The cariogenic risk increases according to food $\mathrm{pH}$, adhesiveness, consistency, occasion and frequency of consumption of cariogenic foods (11-13). In addition, the contribution of breastfeeding to ECC development is controversial (14). Some reports have suggested prolonged and nocturnal breastfeeding as risk factor of ECC (15-17)yet relatively few cohort studies have examined potential dietary risk factors at this age. This study aimed to investigate the associations between feeding frequency at age 12 months and caries prevalence at age 3 years. Methods: In this prospective birth cohort of 345 Brazilian children, all foods and drinks consumed at age
12 months, including bottle-use and breastfeeding, were recorded using two 24-hour infant dietary recalls with mothers. The prevalence of early childhood caries (ECC, meanwhile others have not observed such negative dental effects (18). Considering the lack of evidence, actions towards dental caries prevention are only limited to suggest less frequent breastfeeding intervals once complementary foods have been introduced (15)yet relatively few cohort studies have examined potential dietary risk factors at this age. This study aimed to investigate the associations between feeding frequency at age 12 months and caries prevalence at age 3 years. Methods: In this prospective birth cohort of 345 Brazilian children, all foods and drinks consumed at age 12 months, including bottle-use and breastfeeding, were recorded using two 24-hour infant dietary recalls with mothers. The prevalence of early childhood caries (ECC.

The assessment of the oral health status is the first step for health planners according to the goals of the World Health Organization (WHO) set by 2020 (19). In Ecuador, few studies on ECC have been performed reporting rates up to $52 \%$ (20). The design of regional ECC prevention programs requires research evidence on risk factors associated to this public health problem. In order to contribute to this evidence, this study aimed to evaluate the prevalence and severity of ECC and the risk factors associated with dietary practices 
and nutritional status in infants and preschool children from 10 to 48 months old in Cuenca, Ecuador.

\section{MATERIAL \& METHODS}

The observational study was based on a descriptive cross-sectional design. It was conducted between May 2013 and December 2014 in 142 children of 10-48 months old enrolled at the governmental Child Care Centre (CCC) "Perpetuo Socorro", located in the urban area of Cuenca, Ecuador. All children were eligible, except for those under dental treatment at the time of the study or prolonged antibiotic treatment, and to present tooth enamel defects, mental disabilities and systemic diseases.

Socioeconomic status was assessed applying a survey of the National Institute of Statistics and Censuses of Ecuador (21). Anthropometric measurements were taken in duplicate by trained personnel following standardized methods (22). Weight was measured using an electronic scale SECA model 803 (Hanover, USA) with an accuracy of $0.1 \mathrm{~kg}$. Infant length was measured with a length board SECA model 210 (Hanover, USA) and height of older children was measured using a stadiometer HEALTH-O-METER model Portrod (Alsip, USA), both with an accuracy of $0.1 \mathrm{~cm}$. Z-scores for length-for-age (LAZ), weight-for-age (WAZ) and BMI-for-age were calculated using the WHO 2006 growth standard references (23) and stunting, underweight and overweight were defined following the WHO criteria (24).

To assess dietary patterns and cariogenic foods, parents and home caregivers were surveyed. Information about bottle foods (type and utensils) and added sugar was assessed based on the recommendations of Becerra et al $(1,25)$. Habitual dietary intake was determined by two 24-hours recalls applied on a week and weekend days to the caregivers. Quantification of consumption amounts was performed by comparison with a standardized kit of household containers (26). Food recipes (ingredients, quantities and preparation) served at the CCC followed a set menu that was obtained from the staff. In addition, ingredients were weighted during food preparation as well as the portion served to the child. Information of food recipes received at home was collected from the parents. Food cariogenicity was categorized based on consistency, occasion and frequency of consumption $(12,27)$. For consisten$c y$, individual foods and/or recipes were classified by their moisture content as dry (0-25\%), semi-humid (25.1-62.5\%) and humid (62.6-100\%) $(3,11)$. Foods were also classified according to the moment of consumption, i.e. periods with an interval of at least 2 hours of fasting to allow recovering a normal pH of the saliva (25). Moments of consumption at the CCC were defined as consumption at arrival (around $08 \mathrm{~h} 00$ to $09 \mathrm{~h} 00$ ), at 
mid-morning (10h00-11h00), at lunch (11h3012h30) and at mid-afternoon (15h00-16h00). Moments of consumption outside the CCC corresponded to the period from the exit of the $\mathrm{CCC}$ to the arrival next day. Foods were classified according to the frequency of consumption based on the cariogenic potential value (CAP). This was determined using a daily-consumption frequency survey based on a list of foods containing fermentable sugars which lead to a $\mathrm{pH}$ decrease, enamel demineralization and proliferation of cariogenic bacteria $(12,27)$. The individual cariogenic potential value (CAP) score was calculated using the formula $C A P=(A \times B)+(A \times C)(12,27)$, being $A$ the consumption (sugary drinks, unsweetened masses, candies, sugary masses, sugar); B the frequency ( 0 : no consumption; 1 : consumption of two or more times a week, 2: consumption once a day, and 3: consumption twice or more times a day), and $C$ the occasion (1: cariogenic foods consumption during meals time, and 5 : if the consumption was between meals). Based on the CAP scores, cariogenic risk was categorized as low (10-33); moderate (34-79), and high (80-144) $(12,27)$.

Oral-dental examination was carried out by lastyear Dentistry students under continuous supervision of the researchers that acted as external observers. Followed methods were validated according to WHO criteria $(4,28)$, and an intraand extra-observer concordance of 0.80 of Kappa index was obtained $(5,29)$. Dental examination was performed through clinical observation and exploration with natural light (30) using a standardized diagnostic kit containing a flat mirror \# 5, blunt browser (Medro-german brand), and a WHO periodontal probe (Proclinic) Michigan calibrated with a $0.5 \mathrm{~mm}$ sphere. Children were examined in dorsal-decubitus position, using the knee-knee technique for younger children. After examination, dental plaque was removed with sterile gauze or dental brushing according to the child's age and their collaboration. Flossing was also performed. Löe Silness plaque index (PII) was evaluated after a relative isolation for caries risk categorization (31). Oral cavity was divided into six parts and the free surfaces were inspected: (5-5) (6-1) (6-4) (7- 5) (8-1) (8-4). Tooth in eruption process was discarded from the examination and it was substituted by the contiguous tooth. If one of the target teeth for evaluation was absent, if was subtracted from the total number of surfaces considered for PII calculation. Values assigned to the presence of plaque were 0 (no plaque), 1 (no visible plaque but evidenced with the explorer), 2 (visible plaque) and 3 (visible plaque around the tooth). PII was obtained dividing the total surface score by the total number of surfaces evaluated (4 surfaces $x$ number of teeth). A PII greater than or equal to 1 is considered a caries risk (32).

Presence of dental caries was evaluated according to the clinical criteria of ECC of the Ame- 
rican Academy of Paediatric Dentistry (AAPD) (33) and the International Caries Detection and Assessment System (ICDAS II) (30). ICDAS II diagnosis criteria consider 6 codes: code 0 (sound tooth surface or no evidence of caries after air drying for 5 seconds; surfaces with developmental defects); code 1 (first visual change in enamel characterized as carious opacity or discoloration -white or brown lesion-); code 2 (surfaces with carious opacity -white spot lesion- and/or brown carious discoloration in wet conditions), code 3 (superficial enamel loss of $<0.5 \mathrm{~mm}$ or microcavity on dry enamel, without visible dentin); code 4 (dark dentin shade seen through wet enamel, with or without superficial enamel loss); code 5 (cavity with visible dentin $>0.5 \mathrm{~mm}$ up to $50 \%$ of the dental surface); and code 6 (extensive cavity more than $50 \%$ of the dental surface or crowns destroyed by caries) (34). Incipient or initial caries was defined as the sum of the codes 1 and 2; meanwhile codes 3-6 were considered as cavitated caries (35). Dental caries was also evaluated according to the AAPD criteria that define ECC as the presence of one or more surfaces with caries (cavitated or non-cavitated) or sealed/lost due to caries in children until 71 months old. Additionally, severe ECC was defined as any caries sign on smooth surfaces in children under 3 years-old, when one or more smooth surfaces of upper anterior primary teeth have cavitary lesions, sealed or lost by caries, or when the number of decayed, sealed or lost teeth due to caries was $\geq 4$ teeth at
3 years-old, $\geq 5$ at 4 years-old and $\geq 6$ at 5 yearsold (36).

Descriptive analysis was applied to present the distribution of the participants according to age and sex, nutritional status according to sex, and dietary patterns and dental health according to the child's age. Chi-square tests for categorical variables, meanwhile two sided Student's t-test and analysis of variance were applied for continuous variables. Associations of the studied variables with caries were assessed through bivariate regression models. A linear regression model was used for the continuous ICDAS 3-6 score, whereas a logistic regression model was used for the binary outcomes of initial caries (ICDAS 1-2) and advance caries (ICDAS 3-6).

Data entry was done in duplicate using EpiData software 3.1 (EpiData Association, Odense, Denmark). Lucille food intake 0.1 program was used to process consumption data at individual and group levels, and at the level of total intake, by recipe and by ingredients (37) Data management and analysis were performed in Stata 10.0 (Stata Corporation, College Station, TX) setting statistical significance at $\mathrm{p}$-value less than 0.05 .

The study was approved by the Ethical Committee of the Faculty of Dentistry in Cuenca University (2012), Cuenca, Ecuador (Code number: UC-SFOD-2013-0033-M). After explaining the 
objectives of the study to the CCC authorities, workers and to the parents/caregivers, signed informed consents were obtained prior to the execution of the study. At the end of the study, informative workshops about preventive health and dental hygiene measures were organized for the parents.

\section{RESULTS}

The socioeconomic status of an initial population of 150 participants' households was categorized as $6.7 \%$ medium-high, $25.3 \%$ medium, $46 \%$ medium-low and $22 \%$ low. From it, 142 households decided to participate in the study. The main characteristics of the participants and nutritional status are presented in Table 1. The distribution according to the child's age categories and sex was not homogenous $(p=0.004)$. Regarding nutritional status, a relatively high prevalence of possible risk of overweight in female $(17.7 \%)$ and male children $(23.8 \%)(p=0.668)$ was remarkable.

Child dietary practices according to age are presented in Table 2. The consumption of bottle foods (milk and substitutes) was diverse and varied according to the child's age $(p=0.010)$. Remarkably, cow's milk was the highest consumed beverage $(80.4 \%)$; while very low consumption of breastmilk mixed with cow's milk (8\%) and formula ( $1 \%$ ) was observed, which hindered its
Table 1. Main characteristics and nutritional status of the participants $(n=142)$.

\begin{tabular}{ccccc}
\hline Characteristics & $\begin{array}{c}\text { Pooled } \\
(\mathbf{n}=\mathbf{1 4 2})\end{array}$ & $\begin{array}{c}\text { Male } \\
(\mathbf{n}=\mathbf{8 0})\end{array}$ & $\begin{array}{c}\text { Female } \\
(\mathbf{n}=\mathbf{6 2})\end{array}$ & p-value \\
\hline $\begin{array}{c}\text { Child's age (months) } \\
(\text { mean } \pm \text { SD) }\end{array}$ & $31.8 \pm$ & $30.7 \pm$ & $33.1 \pm$ & 0.169 \\
10-23 months (\%) & $24.7 \%$ & $35 \%$ & $11.3 \%$ & \\
& & 10.8 & 9.7 & \\
24-35 months (\%) & $36.6 \%$ & $30 \%$ & $45.2 \%$ & 0.004 \\
& & & & \\
36-48 months (\%) & $38.7 \%$ & $35 \%$ & $43.5 \%$ &
\end{tabular}

Nutritional status

\begin{tabular}{|c|c|c|c|c|}
\hline $\begin{array}{l}\text { Length-for-age Z-score } \\
\qquad(\text { mean } \pm \mathrm{SD})\end{array}$ & $\begin{array}{c}-1.1 \pm \\
1.1\end{array}$ & $\begin{array}{c}-1.2 \pm \\
1.2\end{array}$ & $\begin{array}{c}-1.0 \pm \\
0.9\end{array}$ & 0.245 \\
\hline Stunted $(<-2 S D)(\%)$ & $15.5 \%$ & $21.3 \%$ & $8.1 \%$ & 0.031 \\
\hline $\begin{array}{l}\text { Weight-for-age Z-score } \\
\qquad(\text { mean } \pm \mathrm{SD})\end{array}$ & $0.4 \pm 0.8$ & $\begin{array}{c}-0.5 \pm \\
0.9\end{array}$ & $\begin{array}{c}-0.3 \pm \\
0.8\end{array}$ & 0.153 \\
\hline $\begin{array}{c}\text { Underweight }(<-2 \mathrm{SD}) \\
(\%)\end{array}$ & $2.8 \%$ & $3.8 \%$ & $1.6 \%$ & 0.445 \\
\hline $\begin{array}{l}\text { BMI-for-age Z-score } \\
\quad(\text { mean } \pm \mathrm{SD})\end{array}$ & $0.5 \pm 0.9$ & $\begin{array}{c}0.4 \pm \\
0.9\end{array}$ & $\begin{array}{c}0.5 \pm \\
0.9\end{array}$ & 0.771 \\
\hline $\begin{array}{l}\text { Possible risk of over- } \\
\text { weight (1-2SD) (\%) }\end{array}$ & $21.1 \%$ & $23.8 \%$ & $17.7 \%$ & 0.668 \\
\hline $\begin{array}{c}\text { Overweight (2-3SD) } \\
(\%)\end{array}$ & $4.2 \%$ & $3.8 \%$ & $4.8 \%$ & \\
\hline
\end{tabular}

Fuente: 
further assessment. The utensils used for bottle foods were also diverse but not significantly different according to age $(p=0.063)$. Caregivers referred that almost all children (92\%) surpassed the global recommendation of limiting sucrose intake to maximum three times a day (38). This sugar consumption showed a slight but not significant increase according to age $(p=0.118)$. In addition, most children received foods with added sugar at night, independently of the child's age (84\%, $p=0.885$ ). Daily consumption of cariogenic foods was significantly different between weekdays $(11.1 \pm 1.4$ foods) compared to the intake during the weekends ( $7.5 \pm 1.8$ foods) $(p<0.001)$. Even though, consumption patterns based on food consistency were similar and considered of low cariogenicity. Watery foods were the most consumed $(73.3 \%$ weekday and $64 \%$ weekend) followed by soft foods ( $19.8 \%$ weekday and 26 $\%$ weekend) without differing significantly according to the child's age $(p=0.454$ and $p=0.323$, respectively). Moreover, the CAP of the weekdays' diet $(33.4 \pm 17.3)$ was also significantly higher than the CAP of the weekends' diet $(28.2 \pm 16.6)$ $(p=0.011)$. However, this was predominantly categorized as low. The number of moments of consumption of cariogenic foods also differed significantly according the main care place of the child, i.e. weekday $(5.1 \pm 0.7)$ vs. weekend (4.3 $\pm 0.9)(p<0.001)$, being similar across age categories ( $p=0.495$ weekday and $p=0.796$ weekend).
The dental health was assessed according to the child's age and these results are presented in Table 3. The prevalence of ECC was remarkably high (95.8\%). Most children (83.1\%) presented advanced caries (ICDAS 3-6). Initial caries decreased statistically according to age $(p=0.004)$, from $33.3 \%$ in the youngest children (10-23 months) to $5.6 \%$ in the oldest group (36-48 months). This matched with the gradual increase of advanced caries prevalence. Code 2 was the most abundant lesion (6.2 \pm 5.4$)$ followed by code 3 (3.3 \pm 3.3) that increases significantly according to the age $(p=0.029$ and $p=0.0001$, respectively). In average, two dental surfaces with serious deterioration were observed in children from 10-35 months old, and three surfaces in children from 36-48 months old. Gradual increase of dental surfaces with non-cavitated and cavitated caries was also dependent of the child's age, reaching an average of $7.1 \pm 6.4$ and $11.1 \pm 9.8$ surfaces at 36-48 months old, respectively. 
Table 2. Child dietary practices according to age categories.

\begin{tabular}{|c|c|c|c|c|c|}
\hline Characteristics & Pooled (\%) & $10-23$ mo (\%) & 24-35 mo (\%) & $36-48 \mathrm{mo}(\%)$ & p-value \\
\hline \multicolumn{6}{|c|}{ Bottle foods given at home $(n=138)$} \\
\hline Cow's milk & 80.4 & 70.6 & 82.4 & 84.9 & \multirow{6}{*}{0.010} \\
\hline Human and cow's milk & 8 & 23.5 & 3.9 & 1.9 & \\
\hline Soy and cow's milk & 8 & 2.9 & 11.8 & 7.6 & \\
\hline Formula & 1.5 & 0 & 0 & 3.8 & \\
\hline Formula and cow's milk & 1.5 & 0 & 2 & 1.9 & \\
\hline Formula and human milk & 0.7 & 2.9 & 0 & 0 & \\
\hline \multicolumn{6}{|c|}{ Utensil used for bottle foods $(\mathrm{n}=138)$} \\
\hline Cup & 61.6 & 47.1 & 68.6 & 64.2 & \multirow{5}{*}{0.063} \\
\hline Cup and bottle & 32.6 & 35.3 & 29.4 & 34 & \\
\hline Cup and breast feeding & 3.6 & 11.8 & 2 & 0 & \\
\hline Cup, bottle and breast feeding & 1.5 & 2.9 & 0 & 1.9 & \\
\hline Bottle and breast feeding & 0.7 & 2.9 & 0 & 0 & \\
\hline \multicolumn{6}{|c|}{ Sugar intake throughout the day ( $n=138)$} \\
\hline 2 times & 2.2 & 5.9 & 2 & 0 & \multirow{3}{*}{0.118} \\
\hline 3 times & 5.8 & 11.8 & 5.9 & 1.9 & \\
\hline$>3$ times & 92 & 82.3 & 92.1 & 98.1 & \\
\hline \multicolumn{6}{|c|}{ Sugar added at night $(\mathrm{n}=117)$} \\
\hline Yes & 84.8 & 82.4 & 86.3 & 84.9 & 0.885 \\
\hline \multicolumn{6}{|c|}{$\begin{array}{l}\text { Daily consumption of cariogenic foods during } \\
\text { weekday (mostly at the care centre) }(\mathrm{n}=121)\end{array}$} \\
\hline Total number of foods (mean \pm SD) & $11.1 \pm 1.4$ & $11.3 \pm 1.7$ & $10.9 \pm 1.4$ & $11.1 \pm 1.2$ & 0.454 \\
\hline Dried foods $(0-25 \% \mathrm{H})$ & 6.9 & 5.3 & 7.0 & 7.7 & \\
\hline Soft foods $(25-62.5 \% \mathrm{H})$ & 19.8 & 22.8 & 20.0 & 18.8 & \\
\hline Watery foods $(62.5-100 \% \mathrm{H})$ & 73.3 & 71.9 & 73.0 & 73.5 & \\
\hline
\end{tabular}




\begin{tabular}{|c|c|c|c|c|c|}
\hline Characteristics & Pooled (\%) & $10-23$ mo (\%) & 24-35 mo (\%) & $36-48 \mathrm{mo}(\%)$ & p-value \\
\hline \multicolumn{6}{|l|}{$\begin{array}{c}\text { Daily consumption of cariogenic foods during } \\
\text { weekend (at home) }(\mathrm{n}=121)\end{array}$} \\
\hline Total number of foods (mean \pm SD) & $7.5 \pm 1.8$ & $7.9 \pm 1.7$ & $7.3 \pm 1.9$ & $7.3 \pm 1.7$ & 0.323 \\
\hline Dried foods $(0-25 \% \mathrm{H})$ & 10 & 13 & 8 & 10 & \\
\hline Soft foods $(25-62.5 \% \mathrm{H})$ & 26 & 25 & 27 & 25 & \\
\hline Watery foods $(62.5-100 \% \mathrm{H})$ & 64 & 62 & 65 & 65 & \\
\hline $\begin{array}{l}\text { Daily CPV - recall from weekday (mostly at the } \\
\text { care centre) }(\mathrm{n}=142)(\text { mean } \pm S D)\end{array}$ & $33.4 \pm 17.3$ & $33.5 \pm 15.8$ & $33.3 \pm 16.5$ & $33.3 \pm 19.1$ & 0.998 \\
\hline Low $(<33)$ & 52.8 & 48.6 & 53.9 & 54.6 & \\
\hline Medium (34-79) & 46.5 & 51.4 & 46.2 & 43.6 & 0.731 \\
\hline High (80-144) & 0.7 & 0 & 0 & 1.8 & \\
\hline $\begin{array}{l}\text { Daily CPV - recall from weekend (at home) } \\
\qquad(\mathrm{n}=142)(\text { mean } \pm S D)\end{array}$ & $28.2 \pm 16.6$ & $25.5 \pm 16.6$ & $27.7 \pm 15.0$ & $30.5 \pm 17.9$ & 0.353 \\
\hline Low $(<33)$ & 64.8 & 77.1 & 61.5 & 60 & \\
\hline Medium (34-79) & 35.2 & 22.9 & 38.5 & 40 & 0.209 \\
\hline High (80-144) & - & - & - & - & \\
\hline \multicolumn{6}{|l|}{ Moments of consumption of cariogenic foods } \\
\hline $\begin{array}{l}\text { During weekday (mostly at the care centre) } \\
(\mathrm{n}=103)(\text { mean } \pm S D)\end{array}$ & $5.1 \pm 0.7$ & $\begin{array}{c}5.1 \pm 0.7 \\
24 \%\end{array}$ & $\begin{array}{c}5.2 \pm 0.7 \\
34 \%\end{array}$ & $\begin{array}{c}5.1 \pm 0.6 \\
42 \%\end{array}$ & 0.495 \\
\hline \multirow[t]{2}{*}{ During weekend (at home) $(\mathrm{n}=105)($ mean $\pm S D)$} & $4.3 \pm 0.9$ & $4.2 \pm 0.7$ & $4.3 \pm 0.9$ & $4.4 \pm 0.9$ & 0.796 \\
\hline & & $26 \%$ & $35 \%$ & $39 \%$ & \\
\hline
\end{tabular}

Table 3. Dental health of the participants according to age categories $(n=142)$.

\begin{tabular}{|c|c|c|c|c|c|}
\hline Characteristics & $\begin{array}{c}\text { Pooled }(\mathrm{n}=142) \\
(\%)\end{array}$ & $\begin{array}{c}10-23 \mathrm{mo}(\mathrm{n}=35) \\
(\%)\end{array}$ & $\begin{array}{c}24-35 \text { mo }(n=52) \\
(\%)\end{array}$ & $\begin{array}{c}36-48 \mathrm{mo}(\mathrm{n}=55) \\
(\%)\end{array}$ & p-value \\
\hline \multicolumn{6}{|l|}{ Early childhood caries by ADA } \\
\hline Healthy children & 4.3 & 14.3 & 0 & 1.8 & \multirow{2}{*}{0.003} \\
\hline Severe caries & 95.8 & 85.7 & 100 & 98.2 & \\
\hline Early childhood caries by ICDAS 1-6 & 95.8 & 85.7 & 100 & 98.2 & 0.003 \\
\hline
\end{tabular}




\begin{tabular}{|c|c|c|c|c|c|}
\hline Characteristics & $\begin{array}{c}\text { Pooled }(\mathrm{n}=142) \\
(\%)\end{array}$ & $\begin{array}{c}10-23 \mathrm{mo}(\mathrm{n}=35) \\
(\%)\end{array}$ & $\begin{array}{c}24-35 \text { mo }(n=52) \\
(\%)\end{array}$ & $\begin{array}{c}36-48 \mathrm{mo}(\mathrm{n}=55) \\
(\%)\end{array}$ & p-value \\
\hline Initial caries (ICDAS 1-2) & 16.9 & 33.3 & 19.2 & 5.6 & \multirow{2}{*}{0.004} \\
\hline Advanced caries (ICDAS 3-6) & 83.1 & 66.7 & 80.8 & 94.4 & \\
\hline ICDAS $0(n=6)^{a, b}$ & $42.0 \pm 29.9$ & $32.8 \pm 22.0$ & - & $88^{c}$ & - \\
\hline ICDAS $1(n=66)$ & $1.6 \pm 2.5$ & $0.5 \pm 1.2$ & $2.0 \pm 3.0$ & $1.8 \pm 2.5$ & 0.015 \\
\hline ICDAS $2(n=128)$ & $6.2 \pm 5.4$ & $4.1 \pm 4.4$ & $6.7 \pm 4.4$ & $7.1 \pm 6.4$ & 0.029 \\
\hline ICDAS $3(n=104)$ & $3.3 \pm 3.3$ & $1.8 \pm 2.9$ & $3.0 \pm 2.8$ & $4.6 \pm 3.4$ & 0.0001 \\
\hline ICDAS $4(n=43)$ & $0.7 \pm 1.4$ & $0.4 \pm 1.1$ & $0.8 \pm 1.5$ & $0.8 \pm 1.3$ & 0.314 \\
\hline ICDAS $5(n=47)$ & $0.9 \pm 1.6$ & $0.6 \pm 1.5$ & $0.8 \pm 1.5$ & $1.1 \pm 1.7$ & 0.265 \\
\hline ICDAS $6(n=47)$ & $2.3 \pm 6.7$ & $1.7 \pm 6.0$ & $1.8 \pm 5.5$ & $3.1 \pm 7.7$ & 0.498 \\
\hline Caries by dental surface and white spot & 95.8 & 85.7 & 100 & 98.2 & 0.003 \\
\hline Number of surfaces with caries & $7.8 \pm 8.9$ & $4.5 \pm 7.4$ & $6.5 \pm 7.9$ & $11.1 \pm 9.8$ & 0.0009 \\
\hline Number of surfaces with white spot & $6.2 \pm 5.3$ & $4.2 \pm 4.3$ & $6.7 \pm 4.4$ & $7.1 \pm 6.4$ & 0.035 \\
\hline Löe -Silness plaque index (PII $\geq 1$ ) & 95.1 & 88.6 & 94.2 & 100 & 0.048 \\
\hline
\end{tabular}

Associations of caries with anthropometric, dietary and dental health-related variables were assessed through bivariate regression models (Table 4). From all tested factors, they showed positive associations with ICDAS 3-6 scores were observed only with the Löe Silness plaque index $(p=0.010 ; 95 \% \mathrm{Cl}: 1.177,8.666)$ and child's age $(p=0.016 ; 95 \% \mathrm{Cl}: 0.032,0.306)$. High plaque index was the most important determinant for the occurrence of advanced caries ( $O R=4.9 ; 95 \%$ $\mathrm{Cl}: 1.331,17.82 ; \mathrm{p}=0.017)$. Moreover, most children showed caries risk (95.1\%) with a significant increase according to age $(p=0.048)$, rising up to $100 \%$ for children of $36-48$ months old. The increment of the child's age was also a positive determinant for the occurrence of advanced caries $(\mathrm{OR}=1.1 ; 95 \% \mathrm{Cl}: 1.041,1.160, \mathrm{p}=0.001)$. Besides, a multiple regression model was constructed with all demographic, nutritional status, dietary factors and plaque index (data not shown). In this adjusted model, child's age increment was the only statistical significant determinant for occurrence of advanced caries $(O R=1.1$; $95 \% \mathrm{Cl}: 1.036,1.223, \mathrm{p}=0.005)$. 
Table 4. Bivariate regression models for ICDAS 3-6 score (linear regression) and for advanced caries (ICDAS 3-6) (logistic regression) $(n=136)$

\begin{tabular}{|c|c|c|c|c|c|c|}
\hline & \multicolumn{3}{|c|}{ ICDAS 3-6 score } & \multicolumn{3}{|c|}{ Advanced caries } \\
\hline & Coefficient & $95 \% \mathrm{CI}$ & p-value & $\begin{array}{l}\text { Odds ratio } \\
\text { (OR) }\end{array}$ & $95 \% \mathrm{CI}$ & p-value \\
\hline Child age (months) & 0.17 & $0.032 ; 0.306$ & 0.016 & 1.1 & $1.041 ; 1.160$ & 0.001 \\
\hline Female gender & -2.32 & $-5.113 ; 0.472$ & 0.103 & 0.8 & $0.327 ; 1.980$ & 0.637 \\
\hline BMI-for-age Z-score & -0.51 & $-2.089 ; 1.074$ & 0.527 & 1.4 & $0.827 ; 2.336$ & 0.214 \\
\hline Length-for-age Z-score & 0.80 & $-0.651 ; 2.250$ & 0.278 & 1.0 & $0.617 ; 1.567$ & 0.942 \\
\hline Weight-for-age Z-score & 0.27 & $-1.461 ; 2.008$ & 0.755 & 1.2 & $0.714 ; 2.177$ & 0.438 \\
\hline Löe Silness plaque index & 4.92 & $1.177 ; 8.666$ & 0.010 & 4.9 & $1.331 ; 17.82$ & 0.017 \\
\hline $\begin{array}{l}\text { Utensil used for bottle foods: Cup } \\
\qquad \& \text { bottle vs. Cup a }\end{array}$ & 1.50 & $-0.282 ; 3.285$ & 0.098 & 1.3 & $0.450 ; 3.580$ & 0.652 \\
\hline Sugar intake throughout the day & 3.71 & $-0.142 ; 7.555$ & 0.059 & 2.3 & $0.869 ; 6.225$ & 0.093 \\
\hline Sugar added at night & 0.23 & $-3.762 ; 4.212$ & 0.911 & 1.3 & $0.391 ; 4.361$ & 0.665 \\
\hline Daily CPV - weekday & -0.002 & $-0.083 ; 0.078$ & 0.950 & 1.0 & $0.973 ; 1.024$ & 0.891 \\
\hline Daily CPV - weekend & 0.016 & $-0.070 ; 0.101$ & 0.713 & 1.0 & $0.982 ; 1.041$ & 0.455 \\
\hline \multicolumn{7}{|l|}{ Cariogenic foods: } \\
\hline $\begin{array}{c}\text { Daily consumption - weekday } \\
\text { Dried foods }\end{array}$ & 1.38 & $-0.381 ; 3.150$ & 0.123 & 1.3 & $0.711 ; 2.383$ & 0.393 \\
\hline Soft foods & -0.035 & $-0.956 ; 0.886$ & 0.940 & 0.9 & $0.703 ; 1.236$ & 0.625 \\
\hline Watery foods & -0.009 & $-0.762 ; 0.745$ & 0.982 & 1.1 & $0.845 ; 1.351$ & 0.580 \\
\hline $\begin{array}{c}\text { Daily consumption - weekend } \\
\text { Dried foods }\end{array}$ & 0.92 & $-0.580 ; 2.418$ & 0.228 & 1.2 & $0.696 ; 1.969$ & 0.552 \\
\hline Soft foods & 0.29 & $-0.693 ; 1.265$ & 0.565 & 0.8 & $0.571 ; 1.072$ & 0.126 \\
\hline Watery foods & 0.44 & $-0.233 ; 1.110$ & 0.199 & 1.2 & $0.941 ; 1.525$ & 0.143 \\
\hline \multicolumn{7}{|l|}{ Moments of consumption } \\
\hline During weekday & 0.42 & $-1.827 ; 2.670$ & 0.711 & 1.1 & $0.470 ; 2.408$ & 0.881 \\
\hline During weekend & 0.39 & $-1.573 ; 2.357$ & 0.693 & 1.5 & $0.791 ; 2.662$ & 0.229 \\
\hline
\end{tabular}

a Regression models were constructed for the most common utensils used for bottle foods: cup \& bottle vs. solely cup $(n=125)$ 


\section{DISCUSSION}

In this study, ECC and associated risk factors (nutritional status and dietary patterns) in Ecuadorian children were evaluated. High prevalence of ECC and Löe Silness plaque index evidenced the deteriorated dental health of the studied population. A similar EEC prevalence has been reported among studies carried out in different developing countries, particularly in vulnerable populations of low socio-economical level (39). Similarly to this study, a high EEC prevalence has been reported in the Peruvian Amazon region (97\%) (40) and it was much higher than in other studies carried out in neighbor regions, such as in La Boquilla, Cartagena, Colombia (60\%) (3); in Calbuco, Chile $(53 \%)(5)$ and in Quito, Ecuador (52\%) (20).

ECC occurrence has been previously associated to the number of teeth erupted, child's age, dietary habits and hygiene practices, as well as social and behavioural determinants such as use of bottle, ethnicity and socio-economic status (39)The increased severity of ECC at older ages has been reported in several publications $(3,5,20,35,40)$. In the present study, the association of child's age with ECC was very remarkable. However, the particular occurrence of non-cavitated lesions (ICDAS 1-2) seemed to follow an opposite trend but it denoted lesions' worsening and a marked increment of cavitated lesions in older children. Irregular oral hygienic practices are also consi- dered as critical risk factors in ECC development $(41,42)$. This is even worsened with high frequency of sugary drinks intake at bedtime (42). Oral hygienic practices could not be successfully assessed in this study due to social constrains. When surveying, caregivers referred to follow the best practices while the opposite was evidenced by clinical examination. To avoid or diminish such social bias, more sensitive strategies to assess oral hygienic practices should be developed and tested.

Dietary habits, especially sugar intake, have an important impact in the development of ECC $(11,17,43)$. It has also been reported that caries development is related to high carbohydrate-low fat diet intake (44). In particular, the influence of the frequent consumption of sucrose between main meals on the initiation and progression of ECC has been highlighted elsewhere (44); meanwhile cow's milk is considered the least cariogenic food (13). In general, the studied dietary practices were considered of low cariogenic risk and no association with ECC was observed. Nevertheless, the delivered diet at childcare center, which is very generic among different public and private care centers, could be improved since this was more cariogenic in comparison to the weekend practices (i.e. mainly at home).

In this study, dietary practices and nutritional status of young children of medium-low socioeconomic status were assessed as risk factors of 
early childhood caries. Advanced caries and white spot were determining epidemiological indicators in this child community. Furthermore, the diagnosis of incipient injuries allowed a complete assessment of dental health, which are not evident by using other indexes.

Child's age and plaque index were identified as determinants of advanced caries, meanwhile diverse aspects that define diet cariogenicity were not associated. Nevertheless, more cariogenic diets might impact considerably on the occurrence of advanced caries and it should be further assessed. Different strategies to improve oral hygiene and dietary practices should be designed and proposed to childcare centres, which are daily sharing school environments that could offer good opportunities to apply those strategies with closely parental involvement.

\section{ACKNOWLEDGEMENTS}

The authors are grateful to the Faculties of Dentistry and Chemical Sciences of Cuenca University for their support to develop this study. We are also grateful with the thesis students that contributed with data collection.

\section{DECLARATION OF CONFLICT OF INTEREST}

The authors hereby declare that there are not conflicts of interest.

\section{FINANCIAL SUPPORT}

This manuscript is a result of a non-financed supported research project.

\section{REFERENCES}

1. World Health Organization. The world health report 2003: shaping the future. 2003. Available from: https://www.who.int/whr/2003/en/whr03_en.pdf

2. Baggio S, Abarca M, Bodenmann P, Gehri M, Madrid C. Early childhood caries in Switzerland: A marker of social inequalities. BMC Oral Health. 2015;15(1):82. https://doi. org/10.1186/s12903-015-0066-y

3. González-Martínez $F$, Sánchez-Pedraza $R$, Carmona-Arango L. Indicadores de Riesgo para la Caries ental en Niños Preescolares de La boquilla Cartagena. Rev Salud Publ. 2009;11(4):620-30. https://doi.org/ 10.1590/ s0124-00642009000400013.

4. Costa LR, Daher A, Queiroz MG. Early childhood caries and body mass index in young children from low income families. Int J Environ Res Pu. 2013;10(3):867-78. https://doi.org/ 10.3390/ ijerph10030867.

5. Zaror Sánchez C, Pineda Toledo P, Orellana Cáceres JJ. Prevalencia de Caries Temprana de 
la Infancia y sus Factores Asociados en Niños Chilenos de 2 y 4 Años. Int J Odontostomatol. 2011;5(2):171-7. https://doi.org/ 10.4067/ s0718-381x2011000200010.

6. Corrêa-Faria P, Paixão-Gonçalves S, Paiva SM, Martins-Júnior PA, Vieira-Andrade RG, Marques LS, et al. Dental caries, but not malocclusion or developmental defects, negatively impacts preschoolers' quality of life. Int J Paediatr Dent. 2016;26(3):211-9. https://doi.org/10.1111/ipd.12190

7. Wigen $\mathrm{TI}$, Wang NJ. Caries and background factors in Norwegian and immigrant 5 -year-old children. Community Dent Oral. 2010;38(1):19-28. https://doi.org/10.1111/ j.1600-0528.2009.00502.x

8. Wulaerhan J, Abudureyimu A, Bao XL, Zhao J. Risk determinants associated with early childhood caries in Uygur children: A preschool-based cross-sectional study. BMC Oral Health. 2014;14(1):136. https://doi.org/ 10.1186/1472-6831-14-136

9. Choi E-J, Lee S-H, Kim Y-J. Quantitative real-time polymerase chain reaction for Streptococcus mutans and Streptococcus sobrinus in dental plaque samples and its association with early childhood caries. Int J Paediatr Dent. 2009 Mar;19(2):141-7. https://
doi.org/10.1111/j.1365-263X.2008.00942.x

10. Folayan MO, Kolawole KA, Oziegbe EO, Oyedele T, Oshomoji O V., Chukwumah NM, et al. Prevalence, and early childhood caries risk indicators in preschool children in suburban Nigeria. BMC Oral Health. 2015;15(1):72. https://doi.org/ 10.1186/s12903-015-0058-y

11. Mobley C, Marshall TA, Milgrom P, Coldwell SE. The Contribution of Dietary Factors to Dental Caries and Disparities in Caries. Academic Pediatrics. 2009;410-4. https://doi. org/ 10.1016/j.acap.2009.09.008

12. Vaisman B, Martinez M. Asesoramiento Dietético Para El Control De Caries En Niños. Rev Latinoam Ortod y Odontoped. 2004;1-11.

13. Nunes AMM, Da Silva AAM, Alves CMC, Hugo FN, Ribeiro CCC. Factors underlying the polarization of early childhood caries within a high-risk population. BMC Public Health. 2014;14(1):988. https://doi.org/10.1186/1471-2458-14-988

14. Arora A, Scott JA, Bhole S, Do L, Schwarz E, Blinkhorn AS. Early childhood feeding practices and dental caries in preschool children: A multi-centre birth cohort study. BMC Public Health. 2011;11:28. https://doi. org/10.1186/1471-2458-11-28 
15. Feldens $C A$, Rodrigues $P H$, de Anastácio $G$, Vítolo MR, Chaffee BW. Feeding frequency in infancy and dental caries in childhood: a prospective cohort study. Int Dent J. 2018;68(2):113-21. https://doi.org/10.1111/ idj.12333

16. Sayegh, A., Dini, E. L., Holt, R. D., \& Bedi R. Oral health, sociodemographic factors, dietary and oral hygiene practices in Jordanian children. J Dent. 2005;33(5):379-88. https:// doi.org/10.1016/j.jdent.2004.10.015

17. Harris NG-G F. Odontología Preventiva Primaria. 6 a edición en inglés, 2 a edición español ed. México. Moderno M, editor. 2005.

18. Mohebbi SZ, Virtanen JI, Vahid-Golpayegani M VM. Feeding habits as determinants of early childhood caries in a population where prolonged breastfeeding is the norm. Community Dent Oral. 2008;36:363-9. https:// doi.org/10.1111/j.1600-0528.2007.00408.x

19. Hobdell M, Petersen PE, Clarkson J, Johnson N. Global goals for oral health 2020. Int Dent J [Internet]. 2003 Oct;53(5):285-8. http:// doi.wiley.com/10.1111/j.1875-595X.2003. tb00761.x

20. Valarezo Bravo T, Mariño Solis S. Prevalencia de caries temprana de la infancia en cuatro guarderías del norte de Quito-Ecuador. Dominio las Ciencias [Internet]. 2017;3(1):278-97. Available from: http://dominiodelasciencias. com/ojs/index.php/es/index

21. Instituto Ecuatoriano de Estadísticas y Censos del Ecuador. Encuesta de Estratificación del Nivel Socioeconómico NSE 2011 [Internet]. 2011. 2011. Available from: www.inec.gob. ec $\% 5 \mathrm{Cr}$

22. Cogill B. Anthropometric Indicators Measurement Guide. Washington, DC: Food and Nutrition Technical Assistance (FANTA) Project, FHI 360. 2003. 23-38 p.

23. Espejo, MR. WHO Child Growth Standards: Methods and Development. J R Stat Soc: Series A (Statistics in Society). 2007; 170(2), 512-512.

24. World Health Organization. Obesity: preventing and managing the global epidemic. Geneva, Switzerland. 2000. Available from: https://www.who.int/nutrition/publications/ obesity/WHO_TRS_894/en/

25. Becerra da Silva L. Tratado de Odontopediatría. In: Tomo 1. 2th ed. Colombia; 2018. p. 489.

26. Ochoa-Avilés A, Verstraeten $R$, Lachat $C$, Andrade S, Van Camp J, Donoso $S$, et al. 
Dietary intake practices associated with cardiovascular risk in urban and rural Ecuadorian adolescents: A cross-sectional study. BMC Public Health. 2014;14(1):939. https://doi.org/10.1186/1471-2458-14-939

27. Giacaman RA, Fernández CE, Díaz S. N. Consumo de carbohidratos fermentables en la dieta medido mediante un sistema de puntaje para la cariogenicidad y experiencia de caries en jóvenes y adultos. Rev Chil Nutr. 2012;39(4):116-22. https://doi.org/10.4067/ S0717-75182012000400002

28. Rubio JM, Salazar FS, Osés JA, González VL. Criterios Mínimos para los Estudios Epidemiológicos dela Salud Dental en Escolares. Rev Esp Salud Publ. 1997;71:231-42. https:// doi.org/10.1590/s1135-57271997000300002

29. Landis JR, Koch GG. The Measurement of Observer Agreement for Categorical Data. Biometrics. 1977;33(1):159. https://doi.org/ $10.2307 / 2529310$

30. Ismail Al, Sohn W TM et al. The International Caries Detection and Assessment System (ICDAS): an integrated system for measuring dental caries. Community Dent Oral. 2007;35(3):170-8. https://doi.org/10.1111/ j.1600-0528.2007.00347.x
31. Löe $H$, Silness J. Periodontal disease in pregnancy I. Prevalence and severity. Acta Odontol Scand. 1963;21(6):533-51. https:// doi.org/10.3109/00016356309011240

32. Silness J, Löe $H$. Periodontal disease in pregnancy II. Correlation between oral hygiene and periodontal condition. Acta Odontol Scand. 1964;22(1):121-35. https:// doi.org/10.3109/00016356408993968

33. Council O. Definition of Early Childhood Caries (ECC). MychildrensteethOrg [Internet]. 2008;4(3):15. Available from: http://www. mychildrensteeth.org/assets/2/7/D_ECC.pdf

34. Shivakumar K, Prasad S, Chandu G. International Caries Detection and Assessment System: A new paradigm in detection of dental caries. J Conserv Dent. 2009;12(1):10. https:// doi.org/ 10.4103/0972-0707.53335

35. Toutouni $H$, Nokhostin M-R, Amaechi BT, Zafarmand $\mathrm{AH}$. The Prevalence of Early Childhood Caries among 24 to 36 Months Old Children of Iran: Using the Novel ICDAS-II Method. J Dent. 2015;16(4):362-36270.

36. American Academy of Pediatric Dentistry A. Policy on early childhood caries (ECC): Classifications, consequences, and preventive strategies. Pediatr Dent. 2018;40(6):60-2. 
37. Universiteit Gent B. 0.1Lfi, Lucille food intake 0.1. 2010.

38. Dean J, Avery D, Mc Donald R. Odontología para el niño y el adolescente. In: Amolca, editor. Odontología para el niño y el adolescente. 9th ed. Colombia; 2014. p. 153.

39. Prakash P, Subramaniam P, Durgesh BH, Konde S. Prevalence of early childhood caries and associated risk factors in preschool children of urban Bangalore, India: A cross-sectional study. Eur J Dent. 2012;6(2):141-52. https:// doi.org/ 10.1055/s-0039-1698943

40. Acosta Yoplac K. Prevalencia de caries y su relación con el estado nutricional en niños de 3 a 5 años de instituciones educativas iniciales de la región Amazonas en el año 2016. Lima, Perú.2019 [Internet]. Universidad Nacional Mayorde San Marcos; 2017. Available from: http://cybertesis.unmsm.edu. pe/bitstream/handle/cybertesis/5586/Acosta_ yk. pdf? sequence $=1$

41. Sun H Bin, Zhang W, Zhou X Bin. Risk Factors associated with Early Childhood Caries. Chin J Dent Res. 2017;20(2):97-104. https://doi.org/ 10.3290/j.cjdr.a38274

42. Hoffmeister L, Moya P, Vidal C, Benadof D. Factors associated with early childhood caries in Chile. Gac Sanit. 2016;30(1):59-62. https:// doi.org/ 10.1016/j.gaceta.2015.09.005

43. Alazmah A. Early childhood caries: A review. J ContempDentPract. 2017;18(8):732-7. https:// doi.org/ 10.5005/jp-journals-10024-2116

44. Gustafsson BE, Quensel CE, Lanke LS, Lundqvist C, Grahnén H, Bonow BE, et al. The effect of different levels of carbohydrate intake on caries activity in 436 individuals observed for five years. Acta Odontol Scand. 1953;11(3-4):232-364. https://doi. org/10.3109/00016355308993925

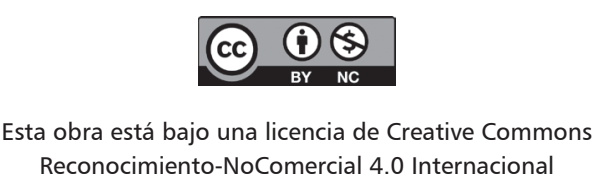

